\title{
The Correlation Between Strong Wind and Leisure Craft Grounding in Croatian Waters
}

\section{Ivan Toman ${ }^{a}$, Đani Mohovićb, Mate Barića, Robert Mohovićc}

This paper examines the correlation between strong wind and the frequency of small leisure craft grounding by analysing the available data on maritime accidents in the Adriatic. The primary goal of this study was to verify the hypothesis from prior research that strong wind is the prime cause of groundings in certain areas of the Adriatic. Contrary to the conclusions of the prior research, the new analysis indicates a far more uniform spatial distribution of wind-caused grounding accidents across all the examined areas of Croatian Adriatic waters. Furthermore, the analysis indicates that most grounding accidents occur in light wind conditions, suggesting that groundings can predominantly be attributed to factors other than strong wind. Several important drawbacks of the analysis stemming from the lack of accurate data on accidents in Croatian waters are discussed and suggestions given for the improved collection thereof that would greatly contribute to the future research on

\section{KEY WORDS}

$\sim$ Grounding accidents

$\sim$ Strong wind

$\sim$ Leisure vessels

$\sim$ Meteorological risks to navigation

$\sim$ Adriatic sea this topic. The inability to determine the exact causes of particular accidents from available data makes it impossible to accurately establish the number of grounding accidents caused by strong wind. In the future, more detailed statistical data could improve our understanding of the correlation between adverse weather conditions and recreational vessel accidents in the Adriatic.

\section{INTRODUCTION}

Nautical tourism is one of the main branches of tourism in Croatia (Favro, 2018). As the traffic of marine leisure vessels, sailboats and yachts significantly intensifies in the Adriatic during the summer, maritime accidents occur far more frequently in this than in other seasons (Mohović, 2013). The impact of unfavourable weather conditions on the safety of navigation tends to increase the risk of accidents especially of small leisure vessels (defined in the Croatian Maritime Code as vessels carrying maximum 12 people, 2.5-15 meters in length, with minimum $5 \mathrm{~kW}$ engines). The main objective of this paper is to establish whether unfavourable weather conditions have an impact on the frequency of maritime accidents in the Adriatic. The correlation between strong wind and grounding accidents is of particular interest for this paper.

In (Frančić, 2009) authors analyse the common causes of maritime accidents in Croatian waters and give recommendations for the improvement of safety of navigation. In that paper, the authors identified grounding as the most common type of accident.

To date there has been no substantial research on the correlation between leisure craft accidents and weather conditions in Croatian scientific papers. The analysis of statistical data in (Mohović, 2013) has shown the number of days with strong wind (Beaufort scale 6 and more) to correlate with the number 
of accidents in some, but not all parts of the Adriatic. (Mohović, 2013) hypothesizes that strong and gale force wind could be an important contributing factor to small craft grounding, but does not give a precise analysis. This paper is a follow-up of the research from (Mohović, 2013), using new statistical data from 2014 to verify its findings and hypothesis and better understand the correlation between strong wind and grounding accidents of small vessels in Croatian waters. Some methodological problems associated with analysis in that paper that might have influenced the conclusions given are identified and discussed at the end of the next chapter.

Many foreign authors have found the correlation between maritime accidents and unfavourable weather conditions. Canadian authors, for example, concluded that, among other conditions, wind speed is an important contributing factor to accidents in Canadian Atlantic waters (Razaee, 2018). In general, the number of maritime accidents increases as weather conditions deteriorate, as shown in ( $\mathrm{Wu}, 2009)$. The analysis of data obtained from three US ports (Kite-Powell, 1999) showed that poor visibility (less than $2 \mathrm{~km}$ ) increases the risk of grounding. The same study found that though strong wind increases the risk of grounding, but not as much as low visibility (Kite-Powell, 1999). Another paper concluded that human causalities in maritime accidents are higher in precipitation and poor visibility conditions (Talley, 2006).

(Otamendi, 2014) found different spatial distribution of accidents among Spanish regions, with the majority of small leisure craft accidents occurring in the north of Spain and the majority of larger leisure craft accidents occurring in the Mediterranean Sea. Authors pointed out the lack of passage planning as major root cause of accidents. Hazardous weather or sea conditions were listed as primary contributing factors to deaths on leisure vessels in the United States 2000-2011, according to (Ryan, 2016).

The primary types of accidents of fishing vessels, in size generally similar to leisure vessels, are foundering and flooding, followed by grounding. Authors indicate engine/gearbox failures, fouled propellers and navigation errors as common causes of fishing boat grounding accidents. Heavy weather damage, as accident type, accounted for less than one percent of all accidents in the UK (Wang, 2005). However, it is not entirely clear if in this paper, for example, grounding caused by strong wind was classified as grounding or a heavy weather accident. Likewise, authors state that smaller vessels are more vulnerable to difficult weather conditions.

This paper tested the hypothesis given in (Mohović, 2013) by comparing the results and conclusions of that study with results obtained by applying the same methodology to new, more detailed data, and identified important differences. Nevertheless, the research is still insufficiently accurate to establish the precise correlation between strong wind and groundings, mainly due to the uncertainty of some aspects of statistical data, as discussed later in this paper. In addition, more research is required to reach detailed conclusions about the statistical distribution of causes of groundings and other accidents in the area of interest.

\section{ANALYSIS OF PREVIOUS RESEARCH}

(Mohović, 2013) as the basis for the research presented in this paper, gives a statistical analysis of data from 2005-2011 for the Croatian part of the Adriatic Sea and the distribution of types and causes of maritime accidents involving leisure vessels. Certain accident reduction and consequence mitigation measures were proposed. For that purpose, the authors used the maritime accident database of the Croatian Maritime Rescue and Coordinating centre (MRCC) - the record of all reported accidents in the Adriatic Sea. The key findings from that research are presented in the following paragraphs along with some modifications to the original analysis made in an attempt to better understand the available data from that paper.

According to (Mohović, 2013), the increase in the number of accidents can be attributed to the increment in the number of leisure vessels. The analysis of accident types has shown the majority of leisure craft accidents to fall under the "Not under Command" and "Grounding" categories. Although the authors indicated various causes of "Not under Command" or "Grounding" accidents, they failed to identify the main causes of accidents from that category due to the limited details offered by the MRCC data obtained. However, as the authors indicated strong wind as one of the possible causes of grounding accidents, they collected data from the Meteorological and Hydrological Service of Croatia for a number of days with strong wind for the counties analysed, for period May to October 2005-2011, when the leisure craft traffic is at its peak, in order to determine whether there is any correlation between the frequency of strong wind and the number of accidents.

Authors of (Mohović et al., 2013) compared the number of recorded maritime accidents in each Croatian county against the estimated nautical tourism leisure craft traffic. As there is no small craft monitoring system in the Adriatic, such traffic can not be precisely quantified. Therefore, the authors of (Mohović et al., 2013) used a proxy measure obtained by adding the number of vessels at permanent berths in nautical ports and the number of recorded transits in ports in each county. Clearly, the figure obtained does not represent the actual number of leisure craft, but the authors surmised that it could be used as an approximation for the comparison of counties. As this paper's objective was to verify the findings of that study using more direct wind data, the methodology for leisure craft traffic estimation for each county used in the original study was duplicated.

The original results of analysis from the paper are presented in Figure 1. 


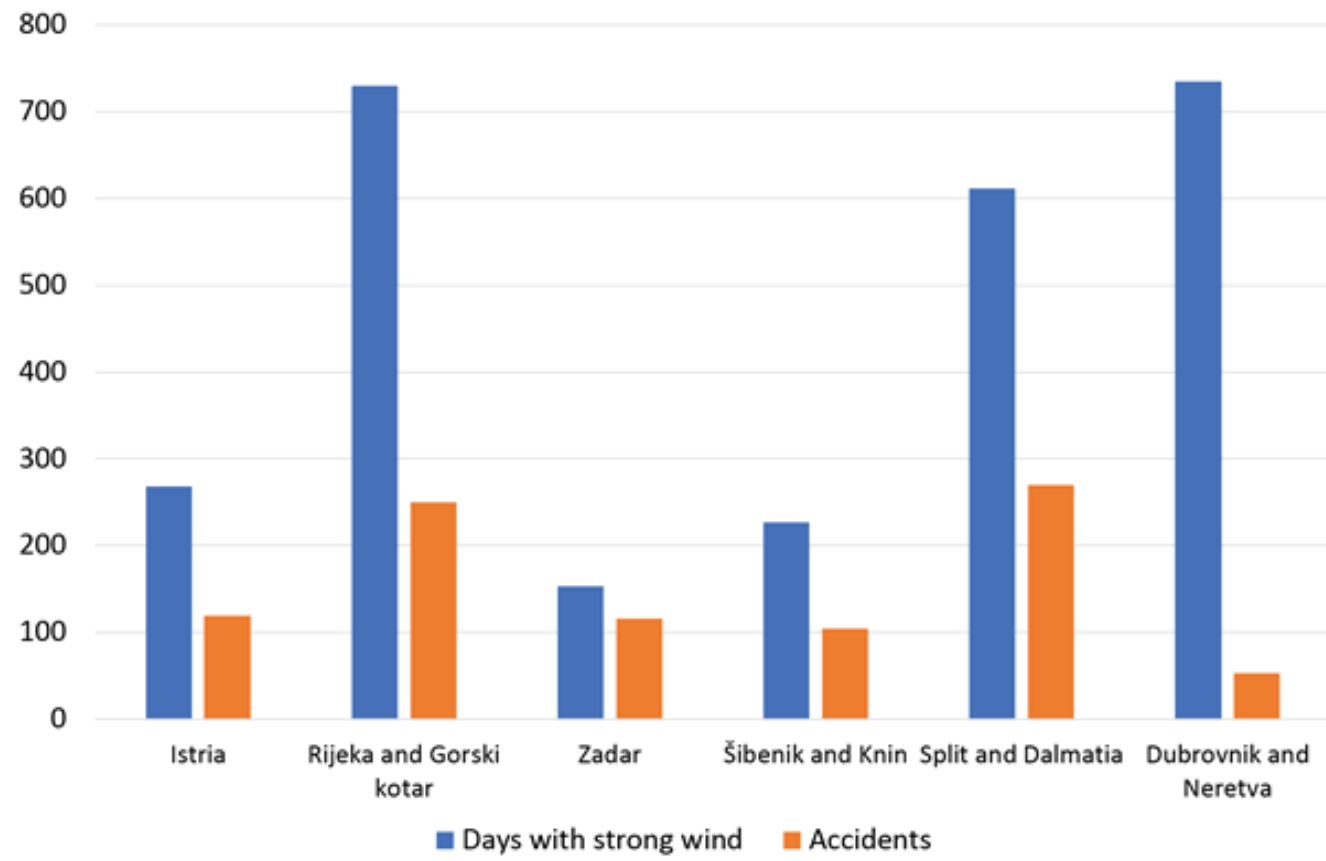

Figure 1.

Total number of accidents (all categories) and total number of days with strong wind, per county, 2005-2011. Sources: (MRCC Rijeka, 2013; DHMZ, 2013), as adapted by (Mohović et al., 2013).

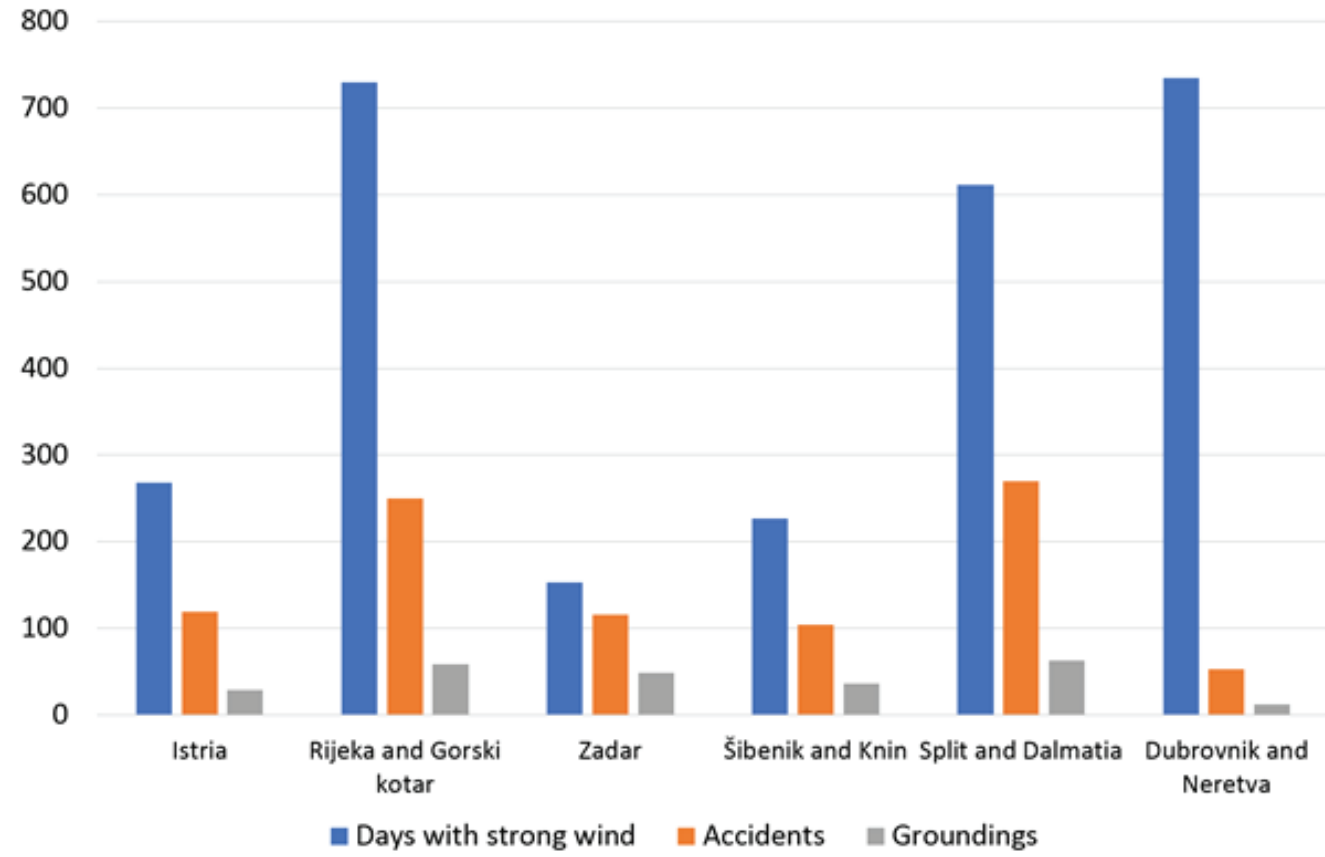

Figure 2.

Comparison of the number of all accidents against the number of groundings and number of days with strong wind, per county, in 2005-2011.

Sources: (MRCC Rijeka, 2013; DHMZ, 2013). 
Though Figure 1 indicates a positive correlation between strong wind and the number of accidents in the Primorje-Gorski Kotar and Split-Dalmatia counties (large number of days with strong wind and large number of accidents), such correlation is not apparent in the Dubrovnik-Neretva County (large number of days with strong wind, but small number of accidents).

However, in the original paper, all accident types were combined and compared against the number of days with strong wind. In addition to such comparison, in order to facilitate a more direct identification of a possible causal relationship, grounding type accidents were separated from other accidents and compared against the numbers of days with strong wind. Figure 2 shows the "grounding" accidents category compared against the total number of accidents and number of days with strong wind in each county.

Figures 1 and 2 indicate a similar correlation between the number of days with strong wind and both the total number of accidents and the number of groundings in all counties. This modified analysis did not yield any new conclusions apart from those already given in the original paper.

However, owing to a huge difference in the number of leisure vessels from county to county, it would also be useful to normalize the number of accidents depending on the number of sailing leisure vessels in each county and then compare that number against the number of days with strong wind. Based on the data from (Mohović, 2013), the number of accidents per million vessels was calculated for each individual county and the results of this modified analysis are given in Table 1. The figures were calculated by dividing the number of accidents with the total number of vessels in the observed period multiplied by million. The "total number of vessels" is the sum of recorded vessels in transit and the number of vessels at permanent moorings, as calculated in (Mohović, 2013). The figure obtained is a proxy measure of traffic quantity for each county, and more data on this method and its shortcomings are provided and discussed later in Chapter 3.

Table 1.

Number of accidents per million vessels, per county, 2005-2011. Source: (MRCC Rijeka, 2013).

\begin{tabular}{lllllll} 
County & Istria & $\begin{array}{l}\text { Rijeka-Gorski } \\
\text { Kotar }\end{array}$ & Zadar & Šibenik-Knin & Split-Dalmatia & $\begin{array}{l}\text { Dubrovnik- } \\
\text { Neretva }\end{array}$ \\
\hline $\begin{array}{l}\text { No. of days with } \\
\text { strong wind }\end{array}$ & 268 & 730 & 153 & 227 & 612 & 735 \\
\hline $\begin{array}{l}\text { No. of accidents } \\
\text { No. of groundings }\end{array}$ & 119 & 250 & 116 & 104 & 270 & 53 \\
\hline $\begin{array}{l}\text { Total number of } \\
\text { leisure vessels }\end{array}$ & 231367 & 191889 & 387324 & 340769 & 260434 & 122059 \\
\hline $\begin{array}{l}\text { Groundings per } \\
\text { million vessels }\end{array}$ & 125.3 & 307.5 & 126.5 & 105.6 & 241.9 & 98.3 \\
\hline
\end{tabular}

The calculated number of groundings per million vessels for each county (Table 1) compared against the number of days with strong wind is given in Figure 3.

Figure 3. Number of groundings per million vessels compared against the number of days with strong wind, for each county, 2005-2011. Sources: (MRCC Rijeka, 2013; DHMZ, 2013).

Figure 3 clearly shows that the variables recorded in the Dubrovnik-Neretva County still significantly deviate from those recorded in other counties.

At the moment, the analysis cannot prove the correlation between the number of days with strong wind and the frequency of leisure vessel groundings, either in absolute or relative terms. The hypothesis is that the correlation found to exist in some counties can be attributed either to chance or increased navigational risks in adverse weather conditions. Further analysis should be performed using different datasets to get a better insight into these correlations.

It should be noted that the analysis of available data on accidents and days with strong wind presented to this point has several important drawbacks that could affect conclusions, and will be discussed in the following paragraphs.

1) The wind data for each county have been obtained by direct measurement at the weather stations of the Croatian Meteorological and Hydrological Service. Each provides data for a single location in the relative vicinity of a navigational area of interest. Currently, there are just a few or only one measurement location per county. More often than not, these single measurement locations do not cover the entire navigational area of the respective county. Due to the local nature of some winds, especially Bora, this is a serious objection to the analysis 


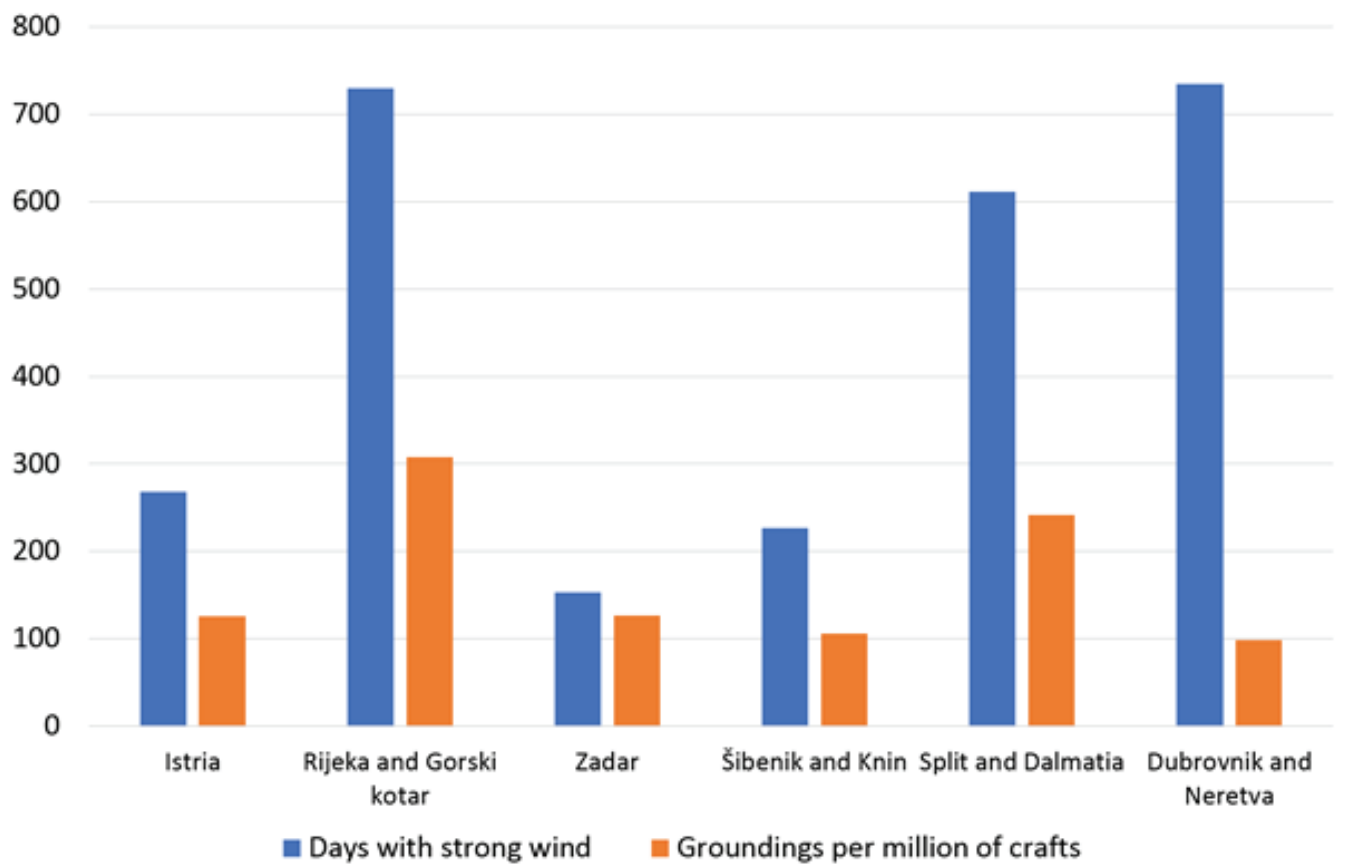

Figure 3.

Number of groundings per million vessels compared against the number of days with strong wind, for each county, 2005-2011.

Sources: (MRCC Rijeka, 2013; DHMZ, 2013).

performed. For example, one of weather stations in the PrimorjeGorski Kotar County is located in the town of Senj, notorious for strong Bora wind. Frequently when there is almost no wind in other parts of the county, that station registers Bora. This can be explained by local topographical properties, as the weather station is located under the low mountain pass Vratnik, that facilitates the unobstructed passage of cold air through the mountain barrier, even in the absence of a strong pressure gradient that would allow Bora to pass over considerably higher areas of Velebit and Kapela mountains. Therefore, significant Bora speeds are recorded only in the limited area around the town of Senj, where the mountain barrier is at its lowest, while the surrounding area has light or even no wind. This can easily corrupt the wind data presented since a false correlation is created due to more windy days being recorded than is realistic for the navigational area of the county as a whole.

2) Wind data are given in the form of the number of days with strong wind, without providing information on the time distribution of strong wind, neither by months nor by time of day, which may be relevant in some circumstances. As the Adriatic is a very large geographical area, similar wind distribution throughout the year or in different times of day cannot be generalized to exist in all of its counties.
3) Only the number of strong wind days is given, without indication of wind direction. As winds of the same speed but different direction are not equally dangerous for navigation, this omission makes the analysis problematic. Experience suggests that the north-easterly wind (Bora) is much more dangerous than the south-easterly wind (Jugo) due to its sudden and gusty nature, resulting in short/steep sea waves that are more dangerous to small vessels than the longer waves produced by the south-easterly or the north-westerly winds. Likewise, the north-easterly wind (more dangerous) is known to be far more common in the northern part of the Adriatic Sea, whereas the south-easterly wind (less dangerous) is more common in the southern parts of the Adriatic. This objection is recognized in the original paper by authors.

\section{METHODS AND RESULTS OF NEW DATA ANALYSIS}

Statistical data collected at MRCC Rijeka since 2014 contain a detailed description of every incident, including the type of accident, the type of the vessel involved, weather and sea conditions in the area. A new analysis was performed using these improved statistical data and compared with the results from (Mohović, 2013). Leisure vessel grounding accident data from 
2014, 2015, 2016 and 2017 have been analysed and compared against weather conditions at the location of the recorded accident.

It is important to note that the weather conditions recorded in the MRCC database pertain to conditions at the time of arrival of the SAR unit to accident location, which reduces the reliability of data as there is no guarantee that weather conditions that led to vessel grounding were the same as conditions at the time of the arrival of the SAR vessel. Average times elapsed between a distress call and arrival at the location of the accident were 0.9 hours in 2014, 1.0 hours in 2015 and 0.66 hours in 2016, while such details were not processed for 2017. The total average time between accident reporting and arrival at the accident location (50 minutes) could mean some difference in weather conditions at the time of the accident and at the time of accident recording.
(Pitman, 2019) discusses how weather conditions can impact the speed of deployment of rescue vessels or helicopters. In addition, weather data recorded in the MRCC database do not provide precise measurements, but are based on the subjective opinion of the SAR unit crew. It is also unknown whether due attention was given to the accurate estimation of weather conditions, especially in case of complex search and rescue operations. The above facts impose important limitations even on this new detailed method of accident data analysis.

Weather data collected in the 4-year period have been divided by Harbour Master's Office (HMO) responsibility areas and wind speed Beaufort categories. The number of groundings, respective wind speed category and accident location are shown in Table 2.

Table 2 .

Number of groundings divided by wind speed data and HMO location, 2014-2017.

Source: (MRCC Rijeka, 2019).

\begin{tabular}{|c|c|c|c|c|c|c|c|}
\hline $\begin{array}{l}\text { Harbour } \\
\text { Master's office }\end{array}$ & Calm & Light breeze & $\begin{array}{l}\text { Moderate } \\
\text { breeze }\end{array}$ & Strong breeze & Gale & Storm & Hurricane \\
\hline Pula & 2 & 7 & 6 & 1 & 0 & 0 & 0 \\
\hline Rijeka & 1 & 5 & 11 & 4 & 0 & 0 & 0 \\
\hline Senj & 0 & 1 & 1 & 1 & 1 & 0 & 0 \\
\hline Zadar & 4 & 12 & 12 & 7 & 0 & 0 & 0 \\
\hline Šibenik & 2 & 10 & 15 & 1 & 1 & 0 & 0 \\
\hline Split & 3 & 18 & 14 & 4 & 1 & 1 & 0 \\
\hline Ploče & 0 & 0 & 1 & 0 & 0 & 0 & 0 \\
\hline Dubrovnik & 2 & 2 & 8 & 2 & 0 & 0 & 0 \\
\hline
\end{tabular}

According to (Bilić, 1999), wind force over 5 Bf (Beaufort scale) is dangerous for small vessels. In Table 2, the groundings in each county are divided into categories depending on Beaufort wind force scale (Frampton, 1988). The groundings were then divided into two groups. The first group are accidents that occurred during level 5 or weaker winds on the Beaufort scale (light wind), and the second group accidents that occurred during level 6 or stronger (strong wind) winds on the Beaufort scale. The results are given in Table 3.

In Table 3, the light/strong ratio represents the number of accidents occurring during light wind ( 5 Bf or less), divided by the number of accidents occurring during strong wind (6 Bf or more). This ratio indicates the areas where a higher percentage of groundings occur during lighter wind (high ratio) and the areas in which the majority of accidents occur during stronger wind (low ratio). For example, 15 times more groundings occurred in winds of $5 \mathrm{Bf}$ or less, than during winds of $6 \mathrm{Bf}$ or more in the HMO Pula area. In contrast to Pula, in the HMO Senj area, the same number of groundings were recorded during 5 or less Beaufort winds and during 6 or more Beaufort wind.

The borders of Croatian Harbour Master's Offices responsibility areas correspond to the borders of Croatian counties, with the exception of the Dubrovnik-Neretva County, where the responsibility is shared between Ploče and Dubrovnik HMOs.

The best measurements of traffic density in individual counties would be monitoring systems covering all types of vessels in an area. If such data were available, traffic density would correspond to the total number of hours away from berth, as accident risk is proportional to time away from berth. However, such data are not available as no monitoring system currently tracks all leisure vessels. The AIS system is an excellent traffic monitoring tool, but is not compulsory on passenger vessels under 300 BT. Due to the unavailability of such data, the same 
Table 3.

Number of grounding occurrences by $\mathrm{HMO}$, during light and strong wind.

Source: taken over from (MRCC Rijeka, 2019) data.

\begin{tabular}{llll} 
Harbour Master's Office & Light wind & Strong wind & Ratio light/strong \\
\hline Pula & 15 & 1 & 15.0 \\
\hline Rijeka & 17 & 4 & 4.3 \\
\hline Senj & 2 & 2 & 1.0 \\
\hline Zadar & 28 & 7 & 4.0 \\
\hline Šibenik & 27 & 2 & 13.5 \\
\hline Split & 35 & 6 & 5.8 \\
\hline Ploče & 1 & 0 & - \\
\hline Dubrovnik & 12 & 2 & 6.0 \\
\hline TOTAL & 137 & 24 & 5.7
\end{tabular}

proxy measure for traffic density in individual areas was used in this paper and in (Mohović et al., 2013). It is the sum of vessels in transit and vessels permanently berthed in nautical tourism ports in a given county. This figure is not an accurate measure, but merely a figure used in calculations to compare counties in terms of groundings per million vessels in order to expand the analysis and verify the conclusions from (Mohović et al., 2013).

The numbers of permanently berthed vessels and vessels in transit in Croatian nautical ports were obtained from the database of the Croatian Bureau of Statistics (DZS, 2019). The data are given in Table 4. The source database does not contain data for the Lika-Senj County.

Table 4.

The total number of permanently berthed vessels and vessels in transit, by county, 2014-2017. Source: (DZS, 2019).

\begin{tabular}{llllll} 
County & 2014 & 2015 & 2016 & 2017 & Total \\
\hline Istria & 25437 & 25416 & 26476 & 22285 & 99614 \\
\hline $\begin{array}{l}\text { Primorje-Gorski } \\
\text { Kotar }\end{array}$ & 22435 & 23622 & 24978 & 23786 & 94821 \\
\hline Zadar & 38301 & 44360 & 37266 & 40337 & 160264 \\
\hline Šibenik-Knin & 44086 & 46375 & 50898 & 52883 & 194242 \\
\hline Split-Dalmatia & 51097 & 52317 & 54945 & 57340 & 215699 \\
\hline Dubrovnik-Neretva & 13759 & 14759 & 17010 & 18698 & 64226 \\
\hline Total & 195115 & 206849 & 211573 & 215329 & 828866 \\
\hline
\end{tabular}

As the Senj-Lika County is not included in the number of vessel statistics, further analysis is performed without that area.

The number of groundings per million leisure vessels for individual counties was calculated for period 2014-2017, regardless of wind conditions at accident location. Results are presented in Table 5.
Next, the number of groundings per million vessels was calculated for the same period, but this time the data were divided depending on wind force. Results are shown in Table 6 and Table 7.

Groundings per million vessels for each scenario (light wind and strong wind) are plotted in Figure 4. 
Table 5 .

Calculated total number of groundings per million vessels, by county, period 2014-2017.

Source: taken over from (MRCC Rijeka, 2019; DZS, 2019) data.

\begin{tabular}{|c|c|c|c|c|c|c|}
\hline County & Istria & $\begin{array}{l}\text { Rijeka-Gorski } \\
\text { Kotar }\end{array}$ & Zadar & Šibenik-Knin & Split-Dalmatia & $\begin{array}{l}\text { Dubrovnik- } \\
\text { Neretva }\end{array}$ \\
\hline $\begin{array}{l}\text { No. of } \\
\text { groundings }\end{array}$ & 16 & 21 & 35 & 29 & 41 & 15 \\
\hline $\begin{array}{l}\text { Total number of } \\
\text { leisure vessels }\end{array}$ & 99614 & 94821 & 160264 & 194242 & 215699 & 64226 \\
\hline $\begin{array}{l}\text { No. of } \\
\text { groundings per } \\
\text { million vessels }\end{array}$ & 160.6 & 221.5 & 218.4 & 149.3 & 190.1 & 233.6 \\
\hline
\end{tabular}

\section{Table 6.}

Calculated number of groundings during light wind, per million vessels, by county, 2014-2017.

Source: taken over from (MRCC Rijeka, 2019; DHMZ, 2019; DZS, 2019) data.

\begin{tabular}{llllll} 
County & Istria & $\begin{array}{l}\text { Rijeka-Gorski } \\
\text { Kotar }\end{array}$ & Zadar & Sibenik-Knin & $\begin{array}{c}\text { Split-Dalmatia } \\
\text { Dubrovnik- } \\
\text { Neretva }\end{array}$ \\
\hline $\begin{array}{l}\text { No. of } \\
\text { groundings } \\
\text { (light w.) }\end{array}$ & 15 & 17 & 28 & 27 & 35 \\
\hline $\begin{array}{l}\text { Total number of } \\
\text { leisure vessels }\end{array}$ & 99614 & 94821 & 160264 & 194242 & 215699 \\
\hline $\begin{array}{l}\text { No. of } \\
\text { groundings per } \\
\text { million vessels }\end{array}$ & 150.6 & 179.3 & 174.7 & 139.0 & 162.3 \\
\hline
\end{tabular}

\section{Table 7.}

Calculated number of groundings during strong wind, per million vessels, by county, 2014-2017.

Source: taken over from (MRCC, 2019; DHMZ, 2019; DZS, 2019) data.

\begin{tabular}{lllllll} 
County & Istria & $\begin{array}{l}\text { Rijeka-Gorski } \\
\text { Kotar }\end{array}$ & Zadar & Šibenik-Knin & $\begin{array}{c}\text { Split-Dalmatia } \\
\text { Dubrovnik- } \\
\text { Neretva }\end{array}$ \\
\hline $\begin{array}{l}\text { No. of } \\
\text { groundings } \\
\text { (strong w.) }\end{array}$ & 1 & 4 & 7 & 2 & 6 & 2 \\
\hline $\begin{array}{l}\text { Total number of } \\
\text { leisure vessels }\end{array}$ & 99614 & 94821 & 160264 & 194242 & 215699 & 64226 \\
\hline $\begin{array}{l}\text { No. of } \\
\text { groundings per } \\
\text { million vessels }\end{array}$ & 10.0 & 42.2 & 43.7 & 10.3 & 27.8 & 31.1 \\
\hline
\end{tabular}


250.0

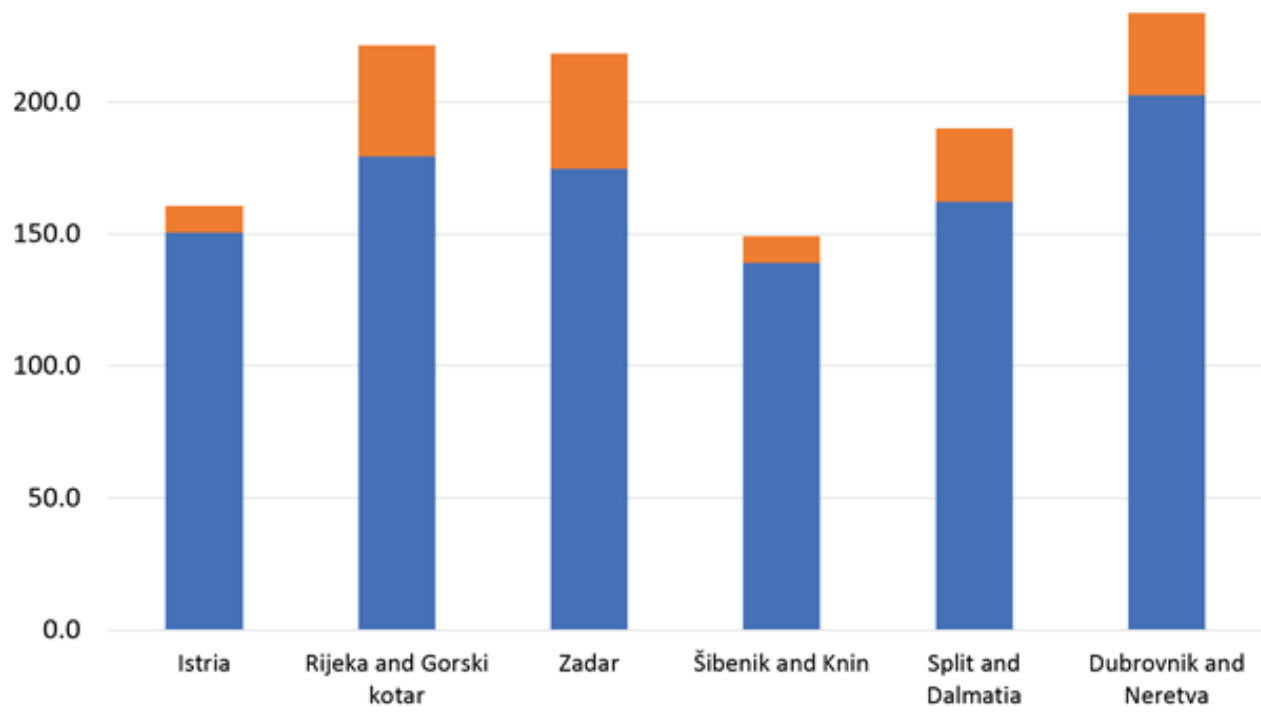

a Groundings per million of crafts, light wind = Groundings per million of crafts, strong wind

${ }^{*}$ Groundings per million vessels

Figure 4.

Number of grounding accidents during light wind and strong wind per county, period 2014-2017.

Source: taken over from (MRCC Rijeka, 2019; DHMZ, 2019; DZS, 2019) data.

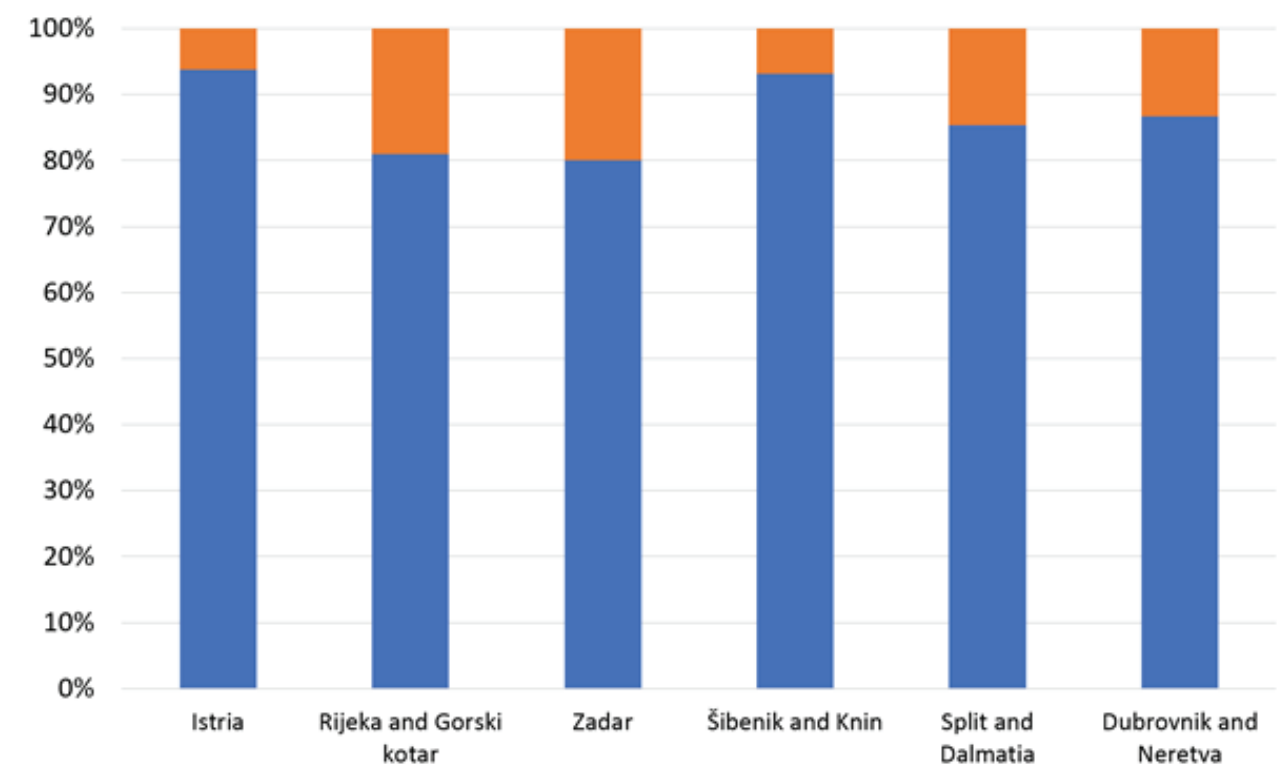

= Groundings per million of crafts, light wind $=$ Groundings per million of crafts, strong wind

*Groundings per million vessels

Figure 5.

Number of grounding accidents during light wind and strong wind by county (stacked plot), period 2014-2017. Source: taken over from (MRCC Rijeka, 2019; DHMZ, 2019; DZS, 2019) data. 
Figure 4 indicates that normalized data (number of groundings per million vessels) are the lowest in the ŠibenikKnin County and the highest in the Dubrovnik-Neretva County. However, if the data are plotted as a percentage, the proper conclusion can be easily derived, as given in Figure 5 .

The data presented in Tables 4, 5 and 6 and Figures 4 and 5 are derived from the total number of leisure vessels in the Croatian nautical ports, i.e. permanently berthed vessels and vessels in transit. As the number of permanently berthed vessels that got out of berth, but rather than reaching another port returned to their permanent berths is unknown, the exact number of vessels sailing in individual counties can not be established. However, as the number of permanently berthed vessels is relatively small compared to the number of vessels in transit (4-12\% of total vessels have permanent berths, depending on county, details at the source (DZS, 2019)), the use of the total number of vessels in the calculations should not significantly affect the final conclusion.

\section{DISCUSSION}

The discrepancy between leisure vessel accidents and strong wind in the Dubrovnik-Neretva County established in (Mohović, 2013) cannot be verified by analysing the available data for 2014-2017. Figure 5 shows similar accident distribution across all counties, regardless of wind speed categories. The highest percentage of groundings during strong wind occurred in the Zadar County (20\%), closely followed by the Rijeka-Gorski Kotar County (19\%), Split-Dalmatia County (15\%), DubrovnikNeretva County (13\%), Šibenik-Knin County (7\%) and finally Istria County (6\%). The number of groundings during strong wind does not exceed the number of groundings during light wind in any county. Therefore, the analysis suggests that strong wind represents similar risk of grounding in every county and that differences between the counties are driven by other factors. This finding differs from the findings presented in (Mohović, 2013).

In the HMO Senj area, the low light/strong wind ratio could be attributed to the most dangerous Bora wind in the area. However, since only 4 groundings were recorded in the HMO Senj area during the observed 4-year period, which is statistically too small a sample, such low ratio could probably be attributed to a large statistical error. The same conclusion can be made in case of HMO Ploče, with only 1 recorded grounding in the 4-year period.

Similar numbers of groundings during light wind were recorded in the Zadar, Šibenik and Split HMOs (28, 27 and 35, respectively). However, only two groundings occurred in the Šibenik HMO during strong wind, compared to 7 in HMO Zadar and 6 in HMO Split. This suggests that factors other than strong wind have a much stronger influence on grounding risk in the Šibenik HMO than in the Zadar and Split HMOs. This is probably due to the fact that the navigational area of the Šibenik HMO is by far the most complex of all HMO areas, with a large number of navigational hazards like shallows and small scattered islands that make navigation challenging, especially to inexperienced leisure craft navigators. In (Belamarić, 2016), some of the risks encountered in the Šibenik area are discussed, particularly the complex navigation through St. Anthony channel. Similar navigational risk analysis was performed in (Đurđević-Tomaš, 2010) for the Dubrovnik area.

Our hypothesis is that most groundings in the Šibenik-Knin County, as the most complex area to navigate, can be attributed to navigational hazards other than strong wind. In contrast to the Šibenik-Knin County, the navigational area of the Istria County is not that complex (for example there aren't so many scattered islands), yet the ratio between groundings during light wind and during strong wind is similar as in the ŠibenikKnin County. Identification of the root cause of these results that would allow us to arrive at detailed conclusions about the causes of groundings and other accidents requires further research, preferably on a larger dataset. Strong wind should be one of the causes of groundings, but analysis to date, given all its limitations, suggests that it is not the prime cause of such incidents.

A very important factor to note is that the analysed period is short - only four years of data, with weather conditions recorded at accident locations. In the observed period, only a small number of groundings have been recorded during strong wind in most of the areas. In addition, since the reliability of weather data recorded at the site of the accidents is questionable, the possibility that such statistical analysis is not completely accurate and that conclusions derived therefrom should be taken with caution is greatly increased. Further research in the field is needed.

Due to the aforementioned limitations of research, the analysis should be repeated after several additional years of data collection, when larger data samples reduce statistical errors. In addition, it would be beneficial to unify and increase the quantity of data collected for individual accidents, as that would improve analysis and conclusion accuracy. Consequently, better accident prevention measures could be proposed that would reduce the number of future accidents.

One of the described limitations is the inability to determine the exact weather conditions at the time of the grounding, because conditions are collected upon the arrival of the SAR vessel at accident location and, as discussed, the average time between the distress call and arrival at the location was 50 minutes. This is not a problem in stable weather conditions, but when conditions change rapidly, the actual weather data may significantly differ from recorded data. For example, if a grounding occurs during a localized thunderstorm in the unstable summer conditions, the SAR vessel would very likely record calm or light wind upon its arrival at the location, although strong wind could have contributed to the grounding accident. 
The above data issues make this type of analysis potentially inaccurate, preventing the researchers from reaching a decisive conclusion on the extent to which strong wind contributes to groundings or other accident types.

Another problem making this type of analysis problematic is that the number of leisure vessels sailing at sea during stable summer weather and during adverse weather conditions is unknown. In most cases, if weather conditions are not favourable, many skippers will decide not to sail out. Consequently, the number of vessels at sea must be much lower than the number of vessels sailing in stable summer weather conditions (Marvasti, 2017). Therefore, the number of accidents should also be lower during strong wind simply owing to a lower number of leisure vessels at sea. This further reduces the ability of researchers to accurately determine the risk of strong wind causing accidents from such statistical data.

In order to make statistical data more useful in the future, additional data for each accident could be collected by HMOs. More accurate data on weather conditions could be obtained and the causality of accidents better determined if following every accident, along with the data currently collected, a questionnaire is presented to the master involved in the accident. The questionnaire could include questions that would give more insight into the cause of the accident, which would greatly contribute to the analysis of statistical data and improve the accuracy of conclusions about the predominant causes of maritime accidents of leisure vessels. Questions that would yield useful data in this respect are what was the cause of the accident according to the master of the vessel, what were the weather conditions at time of the accident, what was the weather forecast prior to the accident and was it sufficiently accurate. Such data could give a much better insight into the causes of accidents and meteorological risks, and benefit future analysis of maritime accidents.

Finally, the traffic quantity/density is unknown as no existing monitoring system covers all leisure vessels. As current legislation does not require (passenger) vessels and yachts under 300 BT to carry an AIS transponder, there is no way to accurately determine the exact number of vessels sailing in the area of interest at any given time. This is yet another uncertainty in research that includes calculations based on traffic density. Another recommendation to the legislator is to extend the AIS carriage requirements to all vessels that can technically accommodate it.

\section{CONCLUSION}

Accidents of small leisure vessels in the summer season are a significant challenge to the safety of navigation in the Adriatic. On the other hand, unfavourable weather conditions could increase the risk of occurrence of leisure craft accidents, particularly grounding, which often results in human causalities, property loss, environmental incidents and puts challenges and inflicts the costs of search and rescue organization.

The analysis based on new data does not confirm the findings from (Mohović et al., 2013) that the correlation between strong wind and leisure vessel grounding differs in different parts of Croatian waters. Our analysis has shown this correlation to be similar in all the areas observed and failed to prove that strong wind is the primary cause of grounding accidents in any area of interest.

Although more detailed as of 2014, statistical data collected for individual accidents still do not give a clear insight into the causes of accidents. The correlation between groundings and strong wind could best be studied if weather conditions at the time of the accident were known. However, as this is not the case, the best the researchers can do is estimate the weather conditions based on the available data recorded upon the arrival of the SAR vessel at the scene of the accident.

The lack of accurate data precludes the clear establishment of the exact cause of grounding, consequently causing problems in the statistical analysis of accident causes. Based on incomplete data available at this point and a relatively small data sample, the analysis presented in this paper suggests that significantly more groundings occur during light than during strong wind in all Croatian Adriatic counties. However, as discussed in the paper, the conclusion that strong wind does not cause significant number of grounding accidents is difficult to prove without more accurate data about each recorded accident. Further research on this topic should focus on a longer time period with greater amount of data and if possible, more information about the causes of accidents should be recorded by the Search and Rescue organization and compulsory AIS carriage should be extended to apply to smaller vessels.

\section{REFERENCES}

Belamarić, G. et al., 2016. Marine Accident Risk Assessment for Port of Šibenik Area. Naše more, 63(4), pp.87-97. Available at:

http://dx.doi.org/10.17818/nm/2016/4.7

Bilić, M., Trošić, Ž., Kasum, J., (1999), Mobitel i sigurnost plovidbe brodica u hrvatskom obalnom moru. Naše more, 46(3-4), pp.119-124. Available at: https:// hrcak.srce.hr/file/307260.

DHMZ (Croatian Meteorological and Hydrological Service) (2019). Official data. Courtesy of DHMZ. Zagreb, Croatia.

DZS (Croatian Bureau of Statistics). Official data. Available at: https://www.dzs.hr [accessed 6 October 2019].

Đurđević-Tomaš, I., Brajović, M. \& Kurtela, Ž., (2010), Analiza rizika pomorskoga prometa u dubrovačkom akvatoriju. Naše more, 57(5-6), pp.215-225. Available at: https://hrcak.srce.hr/62166.

Favro, S., Kovačić, M., (2008), Nautičko gospodarstvo temelj sustavnog razvoja nautičkog turizma. Pomorstvo, 22(1), pp.31-51. Available at: https://hrcak.srce. $\mathrm{hr} / 24797$. 
Frampton, M. \& Uttridge, P.A., (1988), Meteorology for seafarers. Brown, Son \& Ferguson LTD., Nautical Publishers, Glasgow, United Kingdom.

Frančić, V., Njegovan, M. \& Maglić, L., (2009), Analiza sigurnosti putničkih brodova u nacionalnoj plovidbi. Pomorstvo, 23(2), pp.539-555. Available at: https://hrcak.srce. $\mathrm{hr} / 45463$.

Kite-Powell, H., Jin, D., Jebsen, J., Papakonstantinou, V. \& Patrikalakis, N., (1999), Investigation of potential risk factors for groundings of commercial vessels in U.S. ports. International Journal of Offshore and Polar Engineering, 9. Available at: https://www.researchgate.net/publication/254509555_Investigation_of_ Potential_Risk_Factors_For_Groundings_of_Commercial_Vessels_In_US_Ports.

Marvasti, A., 2017. Determinants of the risk of accidents in the Gulf of Mexico commercial fisheries. Ocean \& Coastal Management, 148, pp.282-287. Available at: http://dx.doi.org/10.1016/j.ocecoaman.2017.08.018.

MRCC Rijeka (Maritime Rescue Co-ordination Centre Rijeka) (2019). Official data. Courtesy of MRCC. Rijeka, Croatia.

Ministry of the Sea, Transport and Infrastructure (MPPI): Harbormasters' offices. Available at: http://www.mppi.hr/default.aspx?id=667 [Accessed on: 7th December 2018].

Mohović, Đ., Barić, M., Itković, H., (2013), Contribution to the improvement of the safety of navigation of leisure vessels. Pomorstvo, 27 (1), pp.117-130. Available at: https://hrcak.srce.hr/104191.

Otamendi, F.J. \& González de Vega, J.R., 2014. Recreational boating incidents based on marine surveyors reports: Economic, safety and prevention issues across Spain. Ocean \& Coastal Management, 102, pp.65-71. Available at: http://dx.doi.org/10.1016/j.ocecoaman.2014.09.015.
Pomorski zakonik (Croatian maritime law book) (2020), Available at: https://www. zakon.hr/z/310/Pomorski-zakonik.

Pitman, S.J., Wright, M. \& Hocken, R., 2019. An analysis of lifejacket wear, environmental factors, and casualty activity on marine accident fatality rates. Safety Science, 111, pp.234-242. Available at:

http://dx.doi.org/10.1016/j.ssci.2018.07.016.

Rezaee, S., Pelot, R. \& Finnis, J., 2016. The effect of extratropical cyclone weather conditions on fishing vessel incidents' severity level in Atlantic Canada. Safety Science, 85, pp.33-40. Available at: http://dx.doi.org/10.1016/j.ssci.2015.12.006.

Ryan, K.M. et al., 2016. Injuries and Fatalities on Sailboats in the United States 20002011: An Analysis of US Coast Guard Data. Wilderness \& Environmental Medicine, 27(1), pp.10-18. Available at: http://dx.doi.org/10.1016/j.wem.2015.09.022.

Talley, W.K., Jin, D. \& Kite-Powell, H., 2006. Determinants of the severity of passenger vessel accidents. Maritime Policy \& Management, 33(2), pp.173-186. Available at: http://dx.doi.org/10.1080/03088830600612971.

Wang, J. et al., 2005. An analysis of fishing vessel accidents. Accident Analysis \& Prevention, 37(6), pp.1019-1024. Available at:

http://dx.doi.org/10.1016/j.aap.2005.05.005.

Wu, Y., Pelot, R.P. \& Hilliard, C., 2009. The Influence of Weather Conditions on the Relative Incident Rate of Fishing Vessels. Risk Analysis, 29(7), pp.985-999. Available at: http://dx.doi.org/10.1111/j.1539-6924.2009.01217.x. 